\title{
A.7 National Archives, Kathmandu, Ms. NAK 5/31 = NGMPP B 107-14 ${ }^{11}$
}

A Nepalese paper manuscript of 143 folios. Undated; seemingly from the $19^{\text {th }}$ century. This manuscript is incomplete and no colophon survives. After folio $101 \mathrm{v}$ there are two leaves paginated as 1 and 2 with a numbered list with 137 dhāranīis. ${ }^{12}$ Then leaves in a different hand without foliation follow which contain the Saptaśatikā-prajñāpāramitā as the final colophon shows.

1. Vairocana-nāma-dhāraṇī $1 \mathrm{v}[3]$

2. Akșobhya-nāma-dhāraṇī 1v [4]

3. Ratnasambhava-nāma-dhāraṇī 2r [5]

4. Amitābha-nāma-dhāraṇī 2r [6]

5. Amoghasiddhi-nāma-dhāraṇī 2r [7]

6. Mañjuśrīināma-dhāraṇi $2 r$

7. Mañjuśrībhațạārakasya pratijñā-nāma-dhāraṇī 2v [58]

8. Pañcarakṣā-hṛdaya-mūlavidyā-mahādhāraṇī 3r

9. Āryāvalokiteśvarabhațāārakasya abhayamkkarī-nāma-dhāraṇī 3v [72]

10. Jātismara-nāma-dhāraṇī 4r [36]

11. Svalpākșarā-bhagavatī-prajñāpāramitā-nāma-dhāraṇī 6v [164]

12. Gaṇdavyūhasya-nāma-dhāraṇī 7r [9]

13. Bodhisattvacaryāprasthāna-daśabhūmîsvara-nāma-mahāyānasūtraratnarāja 11v [10]

14. Lañkāvatāra-mahāyānasūtra-paṭhitā-mahāmatiparigṛhītā-nāma-dhāraṇī $14 \mathrm{v}[12]$

15. Saddharmapuṇụarīka-nāma-dhāranī 21r [13]

16. Lalitavistare trapuṣabhallikakalyāṇavākyabhāṣitaparivarta-mahāyānasūtra $25 \mathrm{v}$ [15]

17. Suvarṇaprabhāsottamasūtrendrarāja-nāma-dhāraṇī 34r [16]

18. Bhadracari-nāma-dhāraṇi 38v [70]

19. Sarvapāpadahanī-nāma-dhāraniī 39r [41]

20. Samantajvālāmālāvisphuritacintāmaṇimahāmudrāhṛdayāparājitā-nāmamahādhāraṇī 43r [76?]

11 Titles given with minor standardizations. Corresponding text numbers in Cambridge Ms. Add. 1326 are given in square brackets (there is a chance of inconsistencies in the case of texts which appear by the same title more than once).

12 Note that this list that looks like a table of contents only at places corresponds to the sequence of texts in the actual manuscript. 
21. Mahāmāyūrī-vidyārājñī-tṛtīyamantra-dhāraṇī 46v [79?]

22. Mahāmantrānusāraṇī 48r [81]

23. Mahāśītavatī-nāma-dhāraṇī 49r [80]

24. Karṇajāpā-nāma-dhāraṇī 49v [40]

25. Gāthādvaya-nāma-dhāraṇī 49v [43]

26. Hutāśanatejo-nāma-dhāraṇi 49v [37]

27. Bhaiṣajya-nāma-dhāraṇī 50r [38]

28. Maitreyapratijñā-nāma-dhāraṇī 50v [87]

29. Śākyamunasya dhāraṇī 50v [32?]

30. Sopacāramāṣamukho-nāma-dhāraṇī 51v

31. Sarvaman்gala-dhāraṇī 51v [39]

32. Herukasya sarvarogapraśamanī-nāma-dhāraṇī 52r [144]

33. Ratnacaitya-dhāraṇī 52r

34. Nāmasaṃīti-nāma-dhāraṇī 52v [57,115]

35. Vajraguhyottaraparamatantra-aprameyaphala $53 \mathrm{r}$

36. Suvarṇaprabhā-dhāraṇī 53r

37. Saddharmapuṇdarīkāyā-nāma-dhāraṇī 54r [13]

38. Śākyamunīnāṃ viśeșa-dhāraṇī 54r [35]

39. Mūlavidyā-dhāraṇī 54v [1]

40. Śatottara-nāma-dhāraṇī 55r

41. Ușṇīṣacakravartī-dhāraṇī 55r [50]

42. Daśakrodhamahābhairavasya mahādhāraṇī 55r [114]

43. Vajrapāṇi-mahārakṣā-dhāraṇī 55v [49]

44. Sarvajñatākāra-dhāraṇī 62r [53]

45. Suvarṇaprabhāsūtrendrarāja-sarvabuddhabodhisattva-nāma-saṃdhāraṇī 62v [16]

46. Vajravairocanī-stava-stotra 63r [96]

47. Cintāmaṇi-nāma-dhāraṇī 64r [33,109]

48. Cundābhaț̣ārikāyā mahārakṣā-mantra-dhāraṇī 65r [110]

49. Caturyoga-dhāraṇī $65 \mathrm{r}$

50. Sarvalokeśvara-nāma-dhāraṇī 65v [121]

51. Khasarpaṇā-nāma-dhāraṇī 65v [122]

52. Arapacanamañjuśrī-nāma-dhāraṇī 66r [123]

53. Maitreya-nāma-dhāraṇī 66r [124]

54. Saddharmapāṭha-nāma-dhāraṇī 66r [125]

55. Vajratārā-nāma-dhāraṇi 66v [126]

56. Ugratārā-nāma-dhāraṇī 66v [127]

57. Daśakrodhānāṃ-nāma-dhāraṇī 67r [128]

58. Șaṭpāramitā-hṛdaya-nāma-mahādhāraṇī 68r [59]

59. Bhṛkuṭitārā-nāma-dhāraṇī 68v 
60. Kālacakranibaddha-nāma-dhāraṇī 69r [142]

61. Hevajra-dhāraṇi-pūjā-saṃgraha 70v [143]

62. Vajrasarasvatī-sādhana 71r [93]

63. Mahāsarasvatī-dhāraṇī 71v [94]

64. Hastapūjā-nāma-dhāraṇī 72v [152]

65. Nairātmā-sādhana-dhāraṇī 73r [153]

66. Vajrahūṃkārabhairavasya kavaca-nāma-dhāraṇī 73v [154]

67. Hayagrīva-nāma-dhāraṇī 74r [155]

68. Hayagrīvabhairavasya-nāma-dhāraṇī 75r [156]

69. Gaganātmajaśuklavarṇavajravārāhī-sādhana 77v [158]

70. Bhṛkuṭītārā-nāma-dhāraṇī 77v

71. Trailokyavijayā-nāma-dhāraṇī 78r [175]

72. Vajrayoginì-nāma-dhāraṇī 79r [159]

73. Vajraśrnnkhalā-dhāraṇī 79v [160]

74. Saṃkșipta-śrī-dvibhujaherukasya-nāma-dhāraṇī 81r [161]

75. Pītavarṇa-prajñāpāramitā-nāma-dhāraṇi 81v [162]

76. Vasudhārā-dhāraṇī 82r [165]

77. Sitātapatrāparājitā-nāma-dhāraṇī 82v [166]

78. Vajracarcikā-nāma-dhāraṇī 83r [167]

79. Mahāpratisarāyāḥ sādhana 83v [146]

80. Mahāsāhasrapramardanī-sādhana 84r [148]

81. Mahāmāyūrī-sādhana 84v [147?]

82. Mantrānusāriṇī-sādhana 84v [149]

83. Sītavatī-sādhana 84v [150]

84. Ușnịṣavijayā-sādhana-dhāraṇī 85v [169]

85. Mahāmāyā-nāma-sādhana-dhāraṇī 89r [170]

86. Vajrajvālānalārka-nāma-dhāraṇī 89v [171]

87. Puṇyavivardhanī-nāma-dhāraṇi 92v [52,138?]

88. Kurukullā-nāma-dhāraṇī 93r [95]

89. Mārīcikā-nāma-dhāraṇī 93v [92,102?]

90. Caṇụamahāroṣanasya-nāma-dhāraṇī 94r [172]

91. Hevajrapūjā-nāma-dhāraṇī 95r [143]

92. Mahāmeghanirnādavijụmbhitasuraketu-nāma-dhāraṇī sarvabuddhabhāṣita 101r 